\title{
Too little, too late? The Home Office and the Asbestos Industry Regulations, 1931
}

\author{
PETER BARTRIP*
}

Asbestos is the generic term for a group of fibrous minerals. Virtually indestructible and of high tensile strength, it is both fire and acid resistant, and yet can be spun into yarn and woven into cloth. Although there is evidence of the use of asbestos in the ancient world, it acquired commercial importance only in the late nineteenth century. Thereafter it was employed for numerous purposes, including in fire proofing, insulation and the automobile industry. But, while asbestos was in many ways a boon to humanity, it possesses one major drawback: exposure to its dust can cause fatal diseases, including fibrosis of the lungs (asbestosis) and cancer. As awareness of these dangers emerged, its use came to be first regulated and, subsequently, curtailed, so that today an asbestos industry hardly exists.

While the asbestos industry might be virtually extinct, no branch of the history of occupational health has received more attention than asbestos-related disease. Much of this attention has focused on the USA, but several studies have discussed British developments, particularly during the first third of the twentieth century. ${ }^{1}$ When scholars independently investigate almost any subject, the usual outcome is debate and controversy. However, in relation to asbestos and health there is a high degree of consensus, not only that asbestos was "a bad thing" but that a chapter of errors and omissions occurred in the discovery and eradication of that bad thing. As far as early-twentieth-century Britain is concerned there is broad agreement on a number of points. First, that regulation arrived "late", that is long after the hazards were understood. Second, that certain groups and individuals, including manufacturers, medical scientists, and Factory Inspectors, deserve censure for the belated introduction of regulations. Third, that the regulations were the product of more or less "cosy" negotiations between asbestos manufacturers and civil servants which took little account of trade union views. The purpose of this article is to appraise these assessments, to question the prevailing consensus, and to argue that hitherto studies of the early history of asbestos and occupational health have been dominated by that most beguiling, though misleading, of distractions: hindsight.

\footnotetext{
* Peter Bartrip, PhD, Nene University College Northampton, Park Campus, Boughton Green Road, Kingsthorpe, Northampton, NN2 7AL.

1 See in particular Nick Wikeley, 'The Asbestos Regulations 1931: a licence to kill', J Law Soc., 1992, 19: 365-78; N J Wikeley, Compensation for industrial disease, Aldershot, Dartmouth, 1993; Nick Wikeley, 'Turner \& Newall: early organizational responses to litigation risk', J Law Soc., 1997, 24:
}

252-75; Morris Greenberg, 'Knowledge of the health hazard of asbestos prior to the Merewether and Price report of 1930', Soc. Hist. Med., 1994, 7: 493-516; David J Jeremy, 'Corporate responses to the emergent recognition of a health hazard in the UK asbestos industry: the case of Turner \& Newall, 1920-1960', Bus. econ. Hist., 1995, 24: 254-65; Geoffrey Tweedale and Philip Hansen, 'Protecting the workers: the Medical Board and the asbestos industry, 1930s-1960s', Med. Hist., this issue. 


\section{Peter Bartrip}

It is not easy to establish when it became clear that exposure to asbestos dust posed a health hazard. The conventional view is that the threat was not recognized until the mid to late 1920s. More recently, however, Morris Greenberg, Barry Castleman and others have shown that an asbestos hazard had been identified even before the end of the nineteenth century. Greenberg in particular has gone on to question why it took so many years for the first regulations to be introduced, implying that the Factory Inspectorate was either lax or negligent in permitting an excessive time lag to occur. ${ }^{2}$ But while there are isolated references to the dangers of asbestos from the late 1890s, there was no compelling medical or scientific evidence against asbestos and no sustained call for regulation until the late twenties. By cobbling together various references it is possible to suggest that the hazards of asbestos were fully appreciated by the government in the early $1900 \mathrm{~s}^{3}$ But any such suggestion is misleading and rests heavily, as Robert Murray has argued, upon the use of hindsight. ${ }^{4}$ A sentence in the Senior Medical Inspector's 1927 report provides a different perspective on the issue of government knowledge. "The effect of inhaling the many kinds of dust produced in industry is", John Bridge wrote, "as yet imperfectly understood." Hence it is hard to dispute the views, expressed in 1930 by another Medical Inspector of Factories, Edward Merewether, as to why asbestosis had "only recently attracted notice and become a problem in the industry". 6 These were that:

1. Significant commercial exploitation of asbestos was relatively new. ${ }^{7}$

2. The asbestos industry was small and employed comparatively few workers, particularly in dusty processes. ${ }^{8}$

3. The disease developed slowly and unobtrusively.

4. The disease was easily confused with tuberculosis.

5. Affected workers left the industry and therefore fell out of sight of Factory Inspectors.

6. Medical research on the effects of dust inhalation had concentrated on dusts containing free silica. ${ }^{9}$

To this list might be added a point made by Bridge in his 1928 report, namely, that previous "instructions by Inspectors to press for enclosure of, or the application of exhaust ventilation to, dusty processes in the industry, must have checked the earlier incidence by materially reducing the concentration of dust". ${ }^{10}$

2 Greenberg, op. cit., note 1 above, pp. 493-516.

3 Guardian, 6 Aug. 1982.

4 R Murray, 'Asbestos: a chronology of its origins and health effects', Br. J. ind. Med., 1990, 47: 361-5.

5 PP 1928 Ix, Annual report of the Chief Inspector of Factories and Workshops, 1927, p. 490; see introductory comments to the 1928 report, PP 1929-30 xIII, p. 540.

6 E R A Merewether and C W Price, Report on effects of asbestos dust on the lungs and dust suppression in the asbestos industry, London, HMSO, 1930, p. 17.

7 PP 1929-30 xIII, Annual report of the Chief Inspector of Factories and Workshops, 1928, p. 560.
8 The 1921 census indicated that the industry employed 3762 persons. By 1931 the number had risen to 4286. See Census of England and Wales, 1921. Industry tables, London, HMSO, 1924, table 1, p. 7; Census of England and Wales, 1931. Industry tables, London, HMSO, 1934, table 1, p. 4. In the period 1920-1930 inclusive, the annual average quantity of raw and fibre asbestos imported into the UK for domestic consumption was 19,281 tons. See Annual statement of the trade of the United Kingdom with foreign countries and British possessions, London, HMSO, 1925-1932.

9 Merewether and Price, op. cit., note 6 above, p. 17.

10 PP 1929-30 xIII, Annual report of the Chief Inspector of Factories and Workshops, 1928, p. 560. 


\section{Before the 1920s}

In Britain the first reference to the health hazards of asbestos dates from the 1898 annual report of the Lady Inspectors of Factories. In this the Chief Lady Inspector, Adelaide Anderson, included a section on "certain dusty occupations". Castleman implies that she singled out "asbestos manufacturing processes" for "special attention" because they were particularly dangerous. ${ }^{11}$ In reality, asbestos was only one of four "dusty occupations which specially came under observation in $1898 \ldots$ on account of their easily demonstrated danger to the health of workers, and because of ascertained cases of injury to bronchial tubes and lungs medically attributed to the employment of the sufferers". ${ }^{12}$ As regards asbestos, Anderson noted that:

In the case of one particular asbestos works, which I visited with Miss Deane [another inspector], far from any precaution having been taken, the work (sifting, mixing, and carding) appeared to be carried on with the least possible attempt to subdue the dust; hand labour being used where mechanical connivance was possible to obviate it, and no sort of ventilation being applied. ${ }^{13}$

Deane herself noted that:

The evil effects of asbestos dust have also attracted my attention, a microscopic examination of this mineral dust which was made by H.M. Medical Inspector [Dr Thomas Legge] clearly revealed the sharp, glass-like, jagged nature of the particles, and where they are allowed to rise and to remain suspended in the air of a room, in any quantity, the effects have been found to be injurious, as might have been expected. ${ }^{14}$

Further brief references to asbestos occurred in Anderson's 1899, 1901, 1906, and 1911 reports. In two of these Anderson referred to the preventive measures being introduced by asbestos companies; thus, in 1906 she mentioned an "excellent system of exhaust ventilation" at "one very large asbestos works in the textile district of Lancashire". ${ }^{15}$ In 1910 one of the Medical Inspectors of Factories, Edgar Collis, commented on the subject. ${ }^{16}$ In 1917 the Factory Inspectorate conducted an inquiry into the asbestos hazard but found that "no further evidence incriminating asbestos had come to light either at home or abroad, and therefore no further action could be taken". ${ }^{17}$

These references show that the Factory Inspectorate, including its medical branch, was aware of the potential health hazards of asbestos dust from an early date. Their amalgamation can create the impression that there was great concern within the Inspectorate about the health of asbestos workers. It should be stressed however that these were brief allusions, "sequestered", as Selikoff and Greenberg put it, ${ }^{18}$ in lengthy sets of reports. For example, Anderson's discussion of asbestos in her 1899 report amounted to

11 Barry I Castleman, Asbestos: medical and legal aspects, 4th ed., Englewood Cliffs, Aspen Law \& Business, 1996, p. 2.

12 PP $1900 \mathrm{XI}$, Annual report of the Chief Inspector of Factories and Workshops, 1898, p. 179.

13 Ibid.

14 Ibid., p. 180.

15 PP 1900 XI, Annual report of the Chief Inspector of Factories and Workshops, 1899, p. 544; PP 1902 XXII, Annual report of the Chief Inspector of Factories and Workshops, 1901, p. 244; PP 1907 x, Annual report of the Chief Inspector of Factories and
Workshops, 1906, pp. 237-8; PP 1912-13 xxv, Annual report of the Chief Inspector of Factories and Workshops, 1911, pp. 728-9.

16 PP 1911 xII, Annual report of the Chief Inspector of Factories and Workshops, 1910, p. 620.

17 E R A Merewether, 'A memorandum on asbestosis', Tubercle, 1933-4, 15: 69-81, 109-18, 152-9, p. 72.

18 Irving J Selikoff and Morris Greenberg, 'A landmark case in asbestosis', J. Am. med. Ass., 1991, 265: 898-901, p. 898. 


\section{Peter Bartrip}

less than 6 lines of that year's 536 page annual report of the Chief Inspector of Factories and Workshops. No particular attention was drawn to the asbestos hazard; it was simply one of the many occupational health risks discussed. Until the late 1920s, references to asbestos in Factory Inspectors' reports were short and infrequent. It is hard to establish anything other than that in 1898 , and for the next decade or so, the dangers of the material were slowly beginning to be appreciated.

Occupational health specialists were certainly not sounding alarm bells. Thomas Arlidge's magisterial study of occupational diseases, published in 1892, contained no reference to asbestos. ${ }^{19}$ Thomas Oliver's Dangerous trades (1902) included an essay by Adelaide Anderson on historical aspects of occupational health. In this she supplied the only reference to asbestos in the whole of this 891 page book: "Some of the most injurious processes known to us now are extremely ancient. To mention but a few: lead and quicksilver mining, the potters' craft, and the textile processes of preparing and weaving asbestos and flax". ${ }^{20}$ Oliver was clearly not persuaded of the importance of the asbestos hazard, for he made no mention of it in either of his two most important books on occupational health published after Dangerous trades. ${ }^{21}$ This was despite the fact that both volumes paid considerable attention to "dusty occupations", one of them, Diseases of occupation, having more than 100 pages devoted to the subject. Nor did Edgar Collis mention asbestos-related disease in either his Milroy Lectures on pneumoconioses (1915) or in a co-authored book which appeared in $1921 . .^{22}$ In fact, as late as 1929 the chest specialist, W Burton Wood, confessed that "I have failed to find any mention of asbestos in standard works on pulmonary disease". In the same year Wood's distinguished colleague, S Roodhouse Gloyne, referred to pulmonary asbestosis as a "new" disease. ${ }^{23}$

\section{Merewether and Price}

In the 1920s, following publication in the British Medical Journal of an article by William Cooke, knowledge of the asbestos hazard advanced rapidly. Cooke's paper dealt with the illness and death of Nellie Kershaw, who had been employed in the spinning room of Turner Brothers Asbestos (TBA) of Rochdale, Lancashire. ${ }^{24}$ In 1922, her GP, Walter Joss, diagnosed her as suffering from "asbestos poisoning". ${ }^{25}$ Two years later, at

19 Thomas Arlidge, The hygiene, diseases and mortality of occupations, London, Percival, 1892.

20 Thomas Oliver (ed.), Dangerous trades. The historical, social and legal aspect of industrial occupations as affecting health, by a number of experts, London, John Murray, 1902, p. 25.

21 Thomas Oliver, Diseases of occupation. From the legislative, social and medical points of view, London, Methuen, 1908; idem, Occupations from the social, hygienic and medical points of view, Cambridge University Press, 1916.

22 Edgar L Collis, Industrial pneumoconioses, with special reference to dust phthisis (Milroy Lectures), London, HMSO, 1919; idem, and Major Greenwood, The health of the industrial worker, London, Churchill, 1921.

23 W Burton Wood, 'Radiographic appearances in skiagrams of the chests of workers in asbestos',
Tubercle, 1929, 10: 353-63, p. 353; S Roodhouse Gloyne, 'The presence of the asbestos fibre in the lesions of asbestos workers', Tubercle, 10: 404-7, p. 404.

24 'Fibrosis of the lungs due to the inhalation of asbestos dust', Br. med. J., 1924, ii: 147. The Kershaw case has been described by several authors including Selikoff and Greenberg, op. cit., note 18 above, p. 898; Jeremy, op. cit., note 1 above, 254-65. Turner Brothers Asbestos was one of four companies which, in 1920, came together to form Turner \& Newall. The other three were Newalls Insulation, J W Roberts, and the Washington Chemical Company. See Turner \& Newall Ltd. The first fifty years, 1920-1970, Manchester, T \& N, 1970, p. 3.

${ }^{25} \mathrm{~T} \& \mathrm{~N}$ Archive, Trafford Park, Manchester, drawer 0052, Joss's diagnosis of Nellie Kershaw, 25 July 1922. 
the inquest which followed her death, Cooke testified that "mineral particles in the lungs originated from asbestos and were, beyond reasonable doubt, the primary cause of the fibrosis of the lungs and therefore of death". ${ }^{26}$ In March 1928, following the publication of a number of studies, including a follow-up paper by Cooke, ${ }^{27}$ the Factory Inspectorate became actively involved. Once this happened the progress towards the establishment of regulations was swift.

The subject of asbestos had not figured in the Factory Inspectors' reports since 1911, the results of the 1917 inquiry never having been published. In 1928 it reappeared. In his annual report Bridge outlined the circumstances which precipitated the revival of interest:

In February 1928, Dr. MacGregor, Medical Officer of Health for Glasgow, drew the attention of the Department to an asbestos worker who was receiving treatment in one of the City's Hospitals. This man was suffering from pulmonary fibrosis, which Dr. MacGregor thought might be connected with his employment. The importance of establishing whether the occurrence of this disease in an asbestos worker was merely a coincidence, or evidence of a definite health risk in the industry was apparent, and an inquiry was immediately undertaken to obtain evidence in proof or disproof of the existence of such a risk. ${ }^{28}$

The inquiry, which commenced in March 1928 (that is, before concern about asbestos was first raised in Parliament), was undertaken by one of the Medical Inspectors on Bridge's staff, Edward Merewether. ${ }^{29}$ The results were such that, following the discovery of another case of fibrosis in Leeds, a fuller investigation was ordered, again to be undertaken by Merewether. ${ }^{30}$

Merewether was a newcomer to factory inspection, having taken up his post in 1927. Greenberg implies that his inexperience made him an inappropriate choice for conducting the inquiry, suggesting that his colleagues, Edgar Collis and E L Middleton, who "were of international standing in the field of dust diseases of the lung, would have seemed the obvious candidates". ${ }^{31}$ However, although Merewether was comparatively young (thirtysix years of age in 1928) and inexperienced as a Medical Inspector, he was an accomplished practitioner who went on to have a "long and illustrious career" in industrial medicine, culminating in his appointment as Senior Medical Inspector in $1943 .{ }^{32}$ It is

26 Ibid., inquest on Nellie Kershaw, undated evidence of W E Cooke.

27 W E Cooke, 'Pulmonary asbestosis', Br. med. J., 1927, ii: 1024-5; W E Cooke and C F Hill, 'Pneumokoniosis due to asbestos dust', J. Microscopical Soc., 1927, 47, ser. iii: 232-8; $\mathrm{S}$ McDonald, 'Histology of pulmonary asbestosis', $\mathrm{Br}$. med. J., 1927, ii: 1025-6; Sir Thomas Oliver, 'Clinical aspects of pulmonary asbestosis', Br. med. J., 1927, ii: 1026-7; idem, 'Pulmonary asbestosis in its clinical aspects', J. ind. Hyg., 1927, 9: 483-5; I M D Grieve, 'Asbestosis. An investigation into the chronic pulmonary disease of asbestos workers in this country', MD thesis, University of Edinburgh, 1927.

28 PP 1929-30 XIII, Annual report of the Chief Inspector of Factories and Workshops, 1928, p. 559. This case appears to be that which was written-up by H E Seiler and published in the Br. med. J. (1928, ii: 982): 'A case of pneumoconiosis. result of the inhalation of asbestos dust'.
29 Public Record Office (hereafter PRO) LAB 14/70, Bridge to Gerald Bellhouse (Chief Inspector of Factories), 17 Oct. 1929. The first question in the House of Commons about the danger of asbestos was posed in April 1928, see 5 Hansard, 216: 19 April 1928 , col. 335.

30 PRO LAB 14/70, Bellhouse to Bridge, 2 May 1928 and Bellhouse to Sir John Anderson (Permanent Under-Secretary at the Home Office), 5 July 1928.

31 Greenberg, op. cit., note 1 above, p. 495. Greenberg's statement is bizarre for Collis (1870-1957), distinguished though he was, had left the Factory Inspectorate in 1919! In 1928 he was professor of preventive medicine in the University of Wales medical school. As for Middleton, his absence from leading biographical dictionaries suggests that his international standing was modest.

32 Br. med. J., 1970, i: 571-2, p. 571. 


\section{Peter Bartrip}

difficult to accept, therefore, that he was an unsuitable choice for the investigation. His report favourably impressed the Chief Inspector of Factories, Gerald Bellhouse, the Senior Medical Inspector, John Bridge, and Bridge's predecessor, Legge, who wrote the British Medical Journal's (congratulatory) leading article on it. Bellhouse told the Home Secretary, J R Clynes, that its findings were "of great scientific value", while Bridge described the report as: "the most comprehensive that has yet been written on this aspect of pulmonary disease". Such views are echoed in Merewether's entry in Munk's Roll, where his report is described as "a classic", and elsewhere. ${ }^{33}$

Greenberg also claims that Merewether was concerned to exonerate the Inspectorate for its long neglect of the asbestos problem: "Merewether's report constitutes an apologia for his department". ${ }^{34}$ In view of the praise which has been heaped on the report such a judgment appears harsh. Apart from anything else, Merewether was such a recent recruit to the Inspectorate that he had little need to apologize for its past "failings". If anyone had any reason to rue its tardiness in taking up the asbestos question, it was Thomas Legge with his twenty-eight years experience as a Medical Inspector of Factories. He admitted as much in a book published shortly after his death: "Looking back in the light of present knowledge, it is impossible not to feel that opportunities for discovery and prevention were badly missed." 35 But even this falls short of an admission of negligence or neglect, for who could not look back on a career without acknowledging that, with the benefit of hindsight, they might have acted differently? Legge's reputation, not only as one of the world's leading experts on occupational health, but as a man of high principle who was in sympathy with the worker, was such that, following his resignation from the Civil Service, he joined the Trades Union Congress (TUC) as its medical adviser. ${ }^{36}$

To return to the Factory Inspectorate's inquiry; the thirty-four page report which this yielded comprised two parts; the first, researched and written by Merewether, presented the findings of a clinical and radiological survey of a group of 363 workers who were "constantly exposed in the course of their daily work to the influence of pure or almost pure asbestos dust". ${ }^{37}$ In brief, Merewether concluded that "the inhalation of asbestos dust over a period of years results in the development of a serious type of fibrosis of the lungs" which could lead to "complete disablement and to a fatal termination". Although he dismissed age and gender as risk factors, he considered that both the period of exposure and dust concentrations to which workers were exposed did increase risk. ${ }^{38}$ Although this was gloomy in the extreme, Merewether's findings were not wholly pessimistic. First, he noted that "a certain minimal quantity of the dust" was necessary to bring about fibrosis. Second, "the amount of disablement produced by the development of pulmonary fibrosis in asbestos workers" was "for a number of years . . . surprisingly slight". 39 Third, if

33 PRO LAB 14/70, Bridge to Bellhouse, 17 Oct. 1929; Bellhouse to Merewether, 17 March 1930; Bellhouse to Clynes, 17 March 1930; Br. med. J., 1930, i: 789; Warwick Modern Records Centre (hereafter WMRC), TUC Archive, Silicates-Asbestosis, 1930-1945, MSS.292 144.3/6, Legge to Smyth, 3 April 1930. On Merewether's career and reputation see Gordon Wolstenholme (ed.), Lives of the Fellows of the Royal College of Physicians of London, Oxford and Washington, IRL Press, 1982, pp. 335-6; Br. med. J., 1970, i: 571-2; Lancet, 1970, i: 477-8.
34 Greenberg, op. cit., note 1 above, p. 496.

35 Sir Thomas Legge, Industrial maladies, London, Oxford University Press, 1934, p.191.

36 See Sir Thomas Legge's entry in the New Dictionary of National Biography, Oxford University Press, forthcoming.

37 Merewether and Price, op. cit., note 6 above, p. 7.

38 Ibid., pp. 9, 13 and 15.

39 Ibid., p. 15. 
inhalation of asbestos dust was the cause of fibrosis, then removal of that dust promised to solve the problem. More practically, the reduction of dust would mean a reduction of the hazard. But this raised questions about what would constitute appropriate reductions, both of the dust and of the incidence of fibrosis. Such questions were not easily answered, for, as Merewether pointed out, there were "insuperable difficulties in ascertaining trustworthy figures of the precise incidence of fibrosis amongst workers in particular asbestos processes". However, something which struck Merewether was "the relatively very low incidence rate of fibrosis" amongst spinners. From this he judged that "in order to prevent the full development of the disease within the space of an average working lifetime, it is necessary to reduce the concentration of dust in the air of the workrooms to a figure below that pertaining to spinning at the time over which these cases were exposed" ${ }^{40}$ If this were accomplished Merewether anticipated a favourable outcome:

the application of measures resulting in the reduction of the concentration of dust in the air in the neighbourhood of dusty asbestos processes will cause, firstly, a great increase in the length of time before workers develop a disabling fibrosis, and secondly, the almost total disappearance of the disease, as the measures for the suppression of dust are perfected. ${ }^{41}$

Hence, Merewether felt able to conclude that "the outlook for preventive measures is good. That is to say that in the space of a decade, or thereabouts, the effect of energetic application of preventive measures should be apparent in a great reduction in the incidence of fibrosis". ${ }^{42}$ The second part of the report, written by the Engineering Inspector of Factories, Charles Price, identified the processes which gave rise to dust and recommended various methods for dust suppression. ${ }^{43}$

The question then to be resolved was: what was to be done? In a letter to Bellhouse, written some six months before publication of the Merewether-Price report, Bridge had observed that "regulations ... . will inevitably have to be introduced". Bellhouse's main fear, on seeing Merewether's draft report, was that the "provision of completely adequate mechanical ventilation will not be an easy matter"-hence the instruction to Price to investigate this question further. With Price's report before him Bellhouse's misgivings were lessened, but he recognized that problems remained:

The remedy for these conditions is to be found, as in the case of so many industrial diseases, in the suppression of dust. The second part of the report indicates that this point has only recently been appreciated. As regards the non-textile section of the industry, no serious difficulties arise as regards the application of exhaust ventilation. For the textile section, it is evident that a good deal of experimental work will have to be carried out before completely successful ventilating appliances are evolved effectively to remove all the dust. ${ }^{44}$

By June 1930 the Factory Inspectorate was moving towards the preparation of dust control regulations. Responsibility for this process rested with Duncan Wilson, the Deputy Chief Inspector of Factories, whose first step was to consult Samuel Turner, the Chairman and

40 Ibid., pp. 11-12.

41 Ibid., p. 5.

42 Ibid., pp. 17-18.

43 Ibid., pp. 31-3. Merewether's initial inquiries, which were mainly medical in scope, were conducted by him alone. The submission of his draft report, in
October 1929, raised the question of preventive measures and Price was instructed to investigate. See PRO LAB 14/70, Bellhouse to Anderson, 12 Nov. 1929.

44 PRO LAB 14/70, Bellhouse to Clynes, 17 March 1930. 


\section{Peter Bartrip}

Managing Director of Turner Brothers Asbestos. ${ }^{45}$ Once he had Turner's support, he wrote to the asbestos textile firms informing them of the Inspectorate's intentions and inviting them to a conference to discuss matters. ${ }^{46}$

Such a consultative process had been a regular part of occupational health regulation since the passage of the Factories and Workshops Act, 1891. This Act empowered the Home Secretary to certify any manufacturing trade as dangerous or injurious to health. If he invoked this power, he could then propose a set of "special rules" or require the adoption of such special measures as appeared to the Chief Inspector of Factories "to be reasonably practicable and to meet the necessities of the case". ${ }^{47}$ However, the Home Secretary had no powers of imposition. If employers objected to the rules and could not persuade the Home Office to change its proposals in a way which they deemed to be satisfactory, they could insist on arbitration. In practice, the Home Office did its utmost to avoid alienating employers and becoming involved in arbitrations which were expensive, time-consuming and usually productive only of compromise regulations. Consequently, it usually tried to secure agreement to regulations before their formal issue. This meant that regulating occupational health normally became a consultative exercise. ${ }^{48}$ The 1891 Act was superseded by consolidating legislation in 1901 but while this measure, which remained on the statute book till 1937, removed manufacturers' freedom to insist upon arbitration, it retained their rights of objection and extended them to "persons affected", which could include employees. As a result, it did not change the fact that in practice occupational health regulation was a matter for negotiation rather than dictation. ${ }^{49}$

In his letter to the asbestos firms Wilson informed them that it was the intention of the Chief Inspector of Factories and Workshops to propose a code of regulations for controlling dust. But, he continued, the Chief Inspector "realises . . . that the suppression of dust in many of the processes, particularly those in the textile section of the industry, may often be found to involve problems of considerable difficulty from a mechanical point of view." He therefore proposed "that an informal conference of representatives of the principal textile factories should be held to discuss the best procedure to be adopted in the interests both of his Department and the industry". ${ }^{50}$ This conference, held on 8 July 1930, was attended by six Factory Inspectors and seven representatives of asbestos firms. ${ }^{51}$ Wilson opened proceedings by pointing out that the Merewether-Price report had disclosed "a disquieting situation", in consequence of which the Factory Department would have to recommend to the Home Secretary that he should issue regulations to deal

45 Ibid., Wilson to Anderson, 16 Jan. 1931.

46 Ibid., Wilson to Asbestos Firms, 19 June 1930. While Turner "willingly agreed to provide drawings and full information relating to the methods of ventilation installed", he was not prepared to allow competitor firms access to his premises. Wilson to Anderson, 16 Jan. 1931.

$4754 \& 55$ Vict. c. 75.

48 See P W J Bartrip and R M Hartwell, 'Profit and virtue. Economic theory and the regulation of occupational health in nineteenth and twentieth century Britain', in K O Hawkins (ed.), The human face of law. Essays in honour of Donald Harris, Oxford, Clarendon Press, 1997, pp. 45-63 on pp. 54-5 ; H J Tennant, 'The dangerous trades. A case for legislation' Fortnightly Review, 1898, 71: 316-25, pp. 317-18.

49 Factories and Workshops Act, 1901 (1 Edw.VII c. 22 ss. 79-86). By 1932 forty-three regulatory codes dealing with health hazards in industry had been compiled under the terms of the 1901 Act. See PP 1932-3 XII, Annual report of the Chief Inspector of Factories and Workshops, p. 98.

50 PRO LAB 14/70, Wilson to asbestos firms, 19 June 1930.

51 PRO LAB 14/70, Dust suppression in textile factories. Notes of a conference with asbestos textile manufacturers, 8 July, 1930. 
with the asbestos industry as a dangerous trade. However, he "had visited some of the factories and recognized that the industry wanted to do everything possible for the benefit of their workers". 52 Now this comment might be viewed as mere flattery designed to elicit the co-operation of those attending the conference, but in a private letter to Sir John Anderson, Wilson voiced similar opinions, observing that prior to regulation the leading asbestos firms had already done much to improve health standards, albeit with varying degrees of success. ${ }^{53}$ Certainly, the convergence of opinion at the conference was remarkable and in sharp contrast to some occasions in the past when regulators and manufacturers had been at daggers drawn over the establishment of occupational health regulations. ${ }^{54}$ When the representatives of the asbestos firms gave their views, "all expressed willingness to render every possible assistance and agreed with the object of the Conference". When the question arose of how to proceed further, Wilson suggested the establishment of a small sub-committee, consisting of two Engineering Inspectors and three representatives of the industry, to discuss preventive measures. Because there was some divergence of opinion as to whether this was the best way forward, the employers' representatives conferred in private before acquiescing. Nick Wikeley implies that in agreeing to co-operate the manufacturers were simply safeguarding their own interests: "Presumably the manufacturers took the view-rightly, as it turned out-that their interests would be better protected if they co-operated with the department". ${ }^{55}$ However, there is no evidence to suggest that they were reluctant to introduce dust control measures. Indeed, Bellhouse recorded his "high appreciation of the public spirit shown by the leading manufacturers in this industry, through their ready consent to pool for the benefit of their industry their experiences in regard to the difficult problems to be solved". 56

The sub-committee's first meeting took place on 16 July, after which it met regularly throughout the rest of 1930, completing its report in early January 1931. In undertaking its work, it consulted widely among asbestos manufacturers. The companies whose representatives sat on the sub-committee conducted experiments to determine appropriate methods of ventilation and cleaning, while the Engineering Inspectors, Charles Price and his superior, Leonard Ward, visited factories. ${ }^{57}$ The outcome of its deliberations was a "series of Agreements . . . in most cases embodying specific recommendations for

52 Ibid.

53 Ibid., Wilson to Anderson, 16 Jan. 1931. See also Wilson's observation, in the Annual report of Chief Inspector of Factories and Workshops (PP 1932-3 XII p. 98) that "in many large works... a high standard of ventilation had been attained" before the 1931 Regulations came into effect. Wilson's assessments were endorsed by others. For example, Ian Grieve, a medical practitioner, observed that "the employers are so wide awake to the risks as to establish and enforce precautionary measures on a scale far beyond the requirements of the Factory and Work Shops Act”. Grieve, op. cit., note 27 above, p. 1. In the same year, 1927, Cooke and Hill pointed out that in "modern factories all machines are fitted with covers and the dust removed by extraction". Cooke and Hill, op. cit., note 27 above, p. 233. See also Merewether, op. cit., note 17 above, p. 153.

\footnotetext{
54 The prime example of such conflict is the protracted struggle to control lead poisoning in the pottery and earthenware trade in the 1890 s and early 1900s. PRO HO (Home Office) 45/9852/B12393E and B12393.

55 Wikeley, 'Asbestos Regulations', op. cit., note 1 above, p. 367.

56 Report on conferences between employers and inspectors concerning methods for suppressing dust in asbestos factories, London, HMSO, 1931, pp. 3-4 and 5; T \& N Archive, op. cit., note 25 above, drawer 9044 , notes of conference with asbestos textile manufacturers; see also PP 1930-1 xIII, Annual report of the Chief Inspector of Factories and Workshops, p. 159.

57 T \& N Archive, op. cit., note 25 above, drawer 9044. Papers of the committee for the consideration of dust suppression in asbestos textile factories.
} 


\section{Peter Bartrip}

securing the suppression of dust by exhaust ventilation". ${ }^{58}$ An important aspect of the subcommittee's report was its acceptance of Merewether's judgment that little danger was associated with exposure to dust at concentrations below those which prevailed in spinning departments. As a result, it decided that there were some asbestos processes in which the dust was so low as to be insufficient "in the light of present knowledge, to warrant special recommendations being made for its suppression". Otherwise, "the conditions arising from flyer spinning carried on without exhaust under good general conditions may, it seems to the Committee, be taken as the "dust datum"'. In other words, wherever dust concentrations exceeded those which prevailed in flyer spinning the need for preventive measures was deemed to be established. ${ }^{59}$ The sub-committee stressed that its Agreements were "aimed at interfering as little as possible with existing working methods or lay-out of premises". ${ }^{60}$ Wikeley claims, perhaps on the basis of this statement, that the company representatives on the sub-committee (who were, of course, in a majority) "were prepared to concede to only the minimum level of improvements which were deemed to be essential". ${ }^{61}$ The implication seems to be that they were reluctant regulators. Again, there is no evidence to support Wikeley's point. The sub-committee's report stated that "[t]he Trade representatives on the Committee are unanimous in supporting the Agreements arrived at, as presenting a practicable solution to many of the problems confronting the industry". ${ }^{2}$ For his part, Wilson thanked the manufacturers' representatives on the sub-committee for their "extremely" valuable contributions. ${ }^{63}$ In fact there is no reason to doubt that all parties sincerely, if mistakenly, believed that the introduction of effective exhaust ventilation was all that was required to solve the problem of fibrosis in asbestos factories. As for the sub-committee's point about the need for minimal interference with working methods and premises, this should be seen in the context of a legislative framework which required and permitted only such regulation as was "reasonably practicable".

With the submission of the sub-committee's report, the way was clear, subject to conference accepting it, for the issue of regulations. Conference reconvened on $17 \mathrm{March}$ 1931 and quickly approved, with only minor reservations, the sub-committee's proposals. It then proceeded to discuss the regulations drawn up by the Factory Inspectorate for improving health standards in the asbestos industry. In the course of discussion, the trade representatives raised several objections. First, on the grounds that it would impose an unwarranted burden on the industry, they took "strong exception" to the requirement that records of the compulsory testing of ventilating equipment be kept for examination by a Factory Inspector. Second, on the grounds that it was contrary to normal practice, they objected to having to provide breathing apparatus for workers involved in preparing carding machines for stripping and cleaning. Third, on the grounds that it would interfere

\footnotetext{
58 Ibid., drawer 0089. Report on methods for suppressing dust in asbestos textile factories; Report on conferences, op. cit., note 56 above, p. 6 .

59 Ibid.

60 Ibid., p. 7.

61 Wikeley, 'Asbestos Regulations', op. cit., note 1 above, pp. 367-8. p. 8 .

62 Report on conferences, op. cit., note 56 above,
}

\author{
63 PRO LAB 14/70, Wilson to J Gow, P Fenton \\ and W Kenyon, 16 Feb. 1931; see also WMRC, \\ op. cit., note 33 above, report of meeting with \\ representatives of the unions concerned and \\ deputation to the Deputy Chief Inspector of Factories \\ .. 8 July, 1931; PP 1930-1 XIII, Annual report of \\ the Chief Inspector of Factories and Workshops, \\ p. 159.
}




\section{The Home Office and the Asbestos Industry Regulations, 1931}

with the apprenticeship system, they strongly opposed the exclusion of young persons from certain processes. ${ }^{64}$ Notwithstanding these objections, it should not be thought that the manufacturers had suddenly turned truculent. Far from it, for the Factory Inspectorate saw merit in their arguments. Certainly Bridge, in a letter to the Chief Inspector of Factories, showed that he had much sympathy with their position and was content to see the regulations amended to take some account of their objections, for example, with regard to the suggested exclusion of juveniles. He pointed out that Merewether had rejected the notion that there was any relationship between age and susceptibility to fibrosis. Furthermore, he agreed with the manufacturers that the regulation would prevent the training of young people, and that it would be unnecessary if effective ventilation were installed, since this would remove the risk: "The representatives, rightly I think, emphasized the fact that they hoped with these regulations in force to limit the dust to a degree which would not cause injury to health. Their argument is, I think, a fair one and should be favourably considered". ${ }^{65}$ Subsequently, the clause concerning young persons was amended to the effect that anyone already employed could continue in such employment. However, as Wikeley states, "[i]n other respects . . . relatively few concessions were made to meet the employers' concerns". ${ }^{66}$ In other words, the 17 March conference resulted in the endorsement both of the sub-committee's Agreements and of the Factory Inspectorate's regulations, "subject to a few minor amendments". 67

\section{Organized Labour}

Thus far, this account of the making of the Asbestos Industry Regulations, 1931 has focused on the role of the Factory Inspectorate and the asbestos manufacturers. However, trade unions and the TUC also played significant parts in the regulatory process. Wikeley, while accepting that these bodies were involved, argues that such involvement was ineffectual. Thus, he claims that the TUC was "only able to make improvements at the margins, rather than on fundamental issues"; that it was "unable to achieve any of [its] more far-reaching demands"; and that it "was effectively presented with a fait accompli". ${ }^{68}$ Are these observations valid? TUC files show that its interest in the matter began in April 1930 when Sir Thomas Legge, Congress's part-time medical adviser, wrote to J L Smyth, Secretary of the TUC's Social Insurance Department, on the subject of the recently-published Merewether-Price report. Before considering the involvement of organized labour in the regulatory process, Legge's presence at the TUC requires explanation. After resigning from the Factory Inspectorate in 1926, ill health obliged him to give up work for a time. However, in January 1930, at the age of sixty-six, he took up a post with the TUC. ${ }^{69}$ Legge's presence at Congress at the time that the asbestos regulations were being negotiated was important, for it meant that organized labour had access to a man of vast experience and expertise in occupational health. Indeed, in 1925,

64 PRO LAB 14/70, Notes on the second conference with asbestos manufacturers.

65 Ibid., Bridge to Chief Inspector of Factories, 24 March 1931.

66 Wikeley, 'Asbestos Regulations', op. cit., note 1 above, p. 369.

67 PRO LAB 14/70, Wilson to various asbestos manufacturers , 8 April 1931.

68 Wikeley, 'Asbestos Regulations', op. cit., note 1 above, pp. 369, 370, 375 .

69 Report of the sixty-second annual TUC congress, Nottingham, 1930, London, Co-operative Printing Society, 1930, p. 136. 


\section{Peter Bartrip}

at the time of Legge's knighthood, Duncan Wilson had described him as "the greatest living authority on industrial disease". 70

The question of consulting trade unions was first raised by Wilson in a letter to Sir John Anderson, written in January $1931 .^{71}$ However, by April 1931, that is after the completion of discussions with the manufacturers, nothing had been done. At this point Wilson suggested that the Report on conferences between employers and inspectors be submitted to the TUC for observations prior to publication. ${ }^{72}$ Robert Bannatyne, an Assistant Secretary at the Home Office, informed Congress that, following completion of the Merewether-Price report, a committee consisting of Factory Inspectors and employers' representatives had produced "a most useful series of recommendations" for the suppression of dust in the asbestos industry. The Secretary of State, he explained, intended both to publish the report on the conferences and to issue a code of regulations. Before taking these steps, however, the Home Secretary "would be glad to consider any observations your Council may wish to submit to him on the recommendations contained in the report". ${ }^{73}$ Smyth replied that: "We shall be pleased to furnish you with our comments at an early date and assume that you have sent copies of these documents to the Unions concerned". ${ }^{74}$ It seems likely that Smyth's assumption came as a complete surprise at the Home Office. A civil servant, Edwin Field, telephoned TUC headquarters to explain that the documents had not been sent to individual unions because Home Office officials: ". . . really did not know which unions were concerned, but they were leaving the matter for us [the TUC] to deal with". Meanwhile the Home Office would forward additional copies of the documents for the TUC to distribute. ${ }^{75}$

How did the TUC respond to the papers received from the Home Office? For his part Legge was enthusiastic. He informed the Senior Engineering Inspector, Leonard Ward, that "I have never seen better illustrations of locally applied exhaust ventilation; the doing away with pyramidal hoods and substitution of cover hoods with exhaust connection is a great advance". ${ }^{76}$ A few days later, he repeated this opinion in a letter to Smyth, adding that "[t]he committee [of asbestos manufacturers and Factory Inspectors] does seem to have done its work thoroughly". 77 At the end of May, Smyth notified the Home Office of the TUC's considered view on the proposed regulations. Congress, he said, noted "with satisfaction the complete agreement arrived at by the representatives of the Trade and of the Home Office". The proposed switch from pyramidal to cover hoods was welcomed as "a great improvement". On the other hand, there were misgivings on some points, for example about the value of dust damping. This, it was thought, should be applied only after the "dust datum" had been achieved. The TUC also thought that more consideration should have been given to the use of "Antipoys" respirators and to alternation of employment (i.e. switching people between dangerous and safer jobs). ${ }^{78}$

70 See S A Henry's preface to Legge, op. cit., note 35 above, p. ix.

71 PRO LAB 14/70, Wilson to Anderson, 16 Jan. 1931.

72 Ibid., Wilson to Anderson, 10 April 1931.

73 WMRC, op. cit., note 33 above, Bannatyne to the secretary of the TUC, 24 April, 1931.

74 Ibid., Smyth to Bannatyne, 27 April 1931.

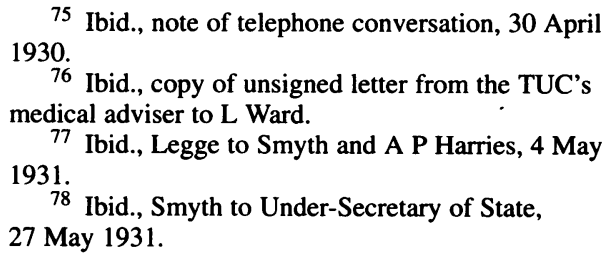


In June, Wilson invited TUC representatives to a meeting, to be held on $8 \mathrm{July}$, at which the points in question could be fully discussed. In his letter of invitation he informed Smyth that inquiries he had made indicated that it would be difficult for the asbestos industry to accept the suggestion for alternating employment. ${ }^{79}$ Subsequently he urged the TUC to "consult as wide a circle as possible on the draft regulations"- -he meant with individual unions_- "so that I may, if possible, be able to submit an agreed code for formal issue" ${ }^{80}$ On 1 July Smyth sent copies of the draft regulations to various unions, inviting them to provide observations and to send a representative to the 8 July meeting. Meanwhile Legge produced detailed comments on the draft regulations. ${ }^{81}$

The 8 July meeting was scheduled to take place at the Home Office at 3.00 p.m. On the morning of the same day trade union representatives, including Legge, held consultations, the outcome of which was nearly three pages of queries. They then proceeded to the Home Office, where they met Wilson, Bridge, Merewether and Price. At the start of the meeting, Wilson explained that he had no power to limit or extend the regulations "but that he wanted to send out a code from the HO which would be agreed to by both the TUC and the employers". In the course of discussion he accepted several of the points made by the union representatives. At the same time he rejected some of their suggestions as either impractical (for example that exhaust ventilation should be mandatory in ship reconditioning jobs), beyond the scope of the Inspectorate's legal powers (for example, that offices, laboratories and other parts of an asbestos works should be sufficiently removed from the manufacturing unit as to ensure that the air was free of fibres), or both unnecessary and certain to provoke objections from employers (particularly the suggestion that the regulations should apply to all asbestos textile processes, including the supposedly safe flyer spinning) ${ }^{82}$ On several of these points the union side was persuaded of the force of Wilson's arguments. At the end of the conference, Wilson said that "he was quite in sympathy with most of the TUC's suggestions and would do all he could to place their views forcibly before the employers". ${ }^{83}$ In the circumstances, Wikeley's comment that "the TUC were unable to achieve any of their more far-reaching demands, although they pressed their amendments on the relatively peripheral matters with some success", is fair, even though it understates the value of some of the points (relating to the use of impermeable sacks and the provision of overalls) on which Wilson gave way. ${ }^{84}$ But equally deserving of emphasis is the point that the employers too were able to modify the rules only at the periphery.

On 14 July Wilson wrote to Smyth clarifying a number of points relating to the conference and assuring him that he had "endeavoured to meet as far as possible the suggestions put forward by the Trades Union Congress". He indicated that he intended to recommend to the Home Secretary that the draft rules should be issued, and invited the

79 Ibid., Wilson to Smyth, 22 June 1931.

80 Ibid., Wilson to Smyth, 1 July 1931. See also the note of Wilson's telephone call, 30 June 1931.

81 Ibid., comments of Legge and Harries, 4 July 1931; PRO LAB 14/70, Smyth to Wilson, 6 July 1931.

82 WMRC, op. cit., note 33 above, report of meeting with representatives of the unions concerned and deputation to the Deputy Chief Inspector of
Factories . . . 8 July, 1931; PRO LAB 14/70, Smyth to Wilson, 6 July 1931 and Wilson to Smyth, 14 July 1931.

${ }^{83}$ WMRC, op. cit., note 33 above, report of meeting with representatives of the unions concerned and deputation to the Deputy Chief Inspector of Factories . . 8 July, 1931.

84 Wikeley, 'Asbestos Regulations', op. cit., note 1 above, p. 370 . 


\section{Peter Bartrip}

TUC, "[i]f . . there still remain points . . . which they desire to press", to pursue them at that stage. Finally, he thanked the TUC for its "helpful contribution . . . to what is necessarily a very difficult problem". ${ }^{85}$ Two days later Wilson wrote to Sir John Anderson enclosing the draft regulations. They were, he said, "based mainly on the agreements arrived at with the representatives of the employers". But a number of suggestions made by the TUC had been incorporated, "the others being regarded as unsuitable". He described the scope of the regulations as "very wide" since they would apply to all factories using asbestos or asbestos articles, the only exceptions being where exposure was occasional or intermittent and ship-board work- "the requirements of the present regulations . . . [being] . . inapplicable to work of this nature". 86

How satisfied was the TUC with the outcome of negotiations? On 20 July Will Sherwood, a member of its 8 July delegation, told Smyth: "While I should have liked to have made one or two further amendments, I believe we have got as far as we can get in this question". Smyth agreed that "we appear to have got as far as we are likely to get at the moment with these Regulations" 87 These remarks were less ringing endorsements for the projected regulations than recognition that in any negotiating process compromises have to be made. However, Legge provided a much more positive appraisal. He felt that, following publication of Cooke's 1924 paper, the Home Office had "set speedily to work" to resolve the asbestos problem. He warmly approved the co-operation shown by Factory Inspectors and asbestos manufacturers: "It is a pleasing instance of the readiness now of leading manufacturers in an industry to combine with the Factory Department to do everything practically possible to suppress dust and to pool for the benefit of their industry their experiences in regard to the problems to be solved". That such problems had to be solved was, in Legge's opinion, vital for two reasons. First, there was no "comparatively harmless form of asbestos" and, second, there was no suitable alternative to asbestos. That such views were held by Legge is particularly significant for he had resigned from the Factory Inspectorate in protest against the British government's failure to ban the use of lead in paint when suitable alternatives were available; in other words, he was not necessarily averse to proscription. Legge's final assessment of the proposed regulations was that they "will mark a great advance and perhaps, as the measures for the suppression of dust take effect, will bring about the almost total disappearance of the disease". ${ }^{88}$ Within a few weeks Smyth seems to have come round to much the same opinion for he informed Wilson of his pleasure at having been able to render assistance in the rulemaking process and of his hope that the regulations "will result in a very big improvement in the health of the workers in the asbestos industry". 89

The Home Office issued draft regulations on 15 September 1931. There were no objections from asbestos companies and only one from the TUC. The TUC's related to "one small point" in that section of Rule 12 which permitted a young person already employed in a process from which the employment of juveniles was to be prohibited, to continue in such employment. In January 1932 the Secretary of State dismissed the

85 PRO LAB 14/70, Smyth to Wilson, 6 July 1931, and Wilson to Smyth, 14 July 1931.

86 Ibid., unsigned and incomplete letter, Wilson to Anderson, 16 July 1931.

87 WMRC, op. cit., note 33 above, Sherwood to
Smyth, 20 July 1931; Smyth to Sherwood, 21 July 1931; Sherwood to Smyth, 16 Sept. 1931.

88 Ibid., Legge's memorandum, 21 July 1931.

89 PRO LAB 14/70, Smyth to Wilson, 1 Sept. 1931. 
objection..$^{90}$ The Asbestos Industry Regulations, dated 31 December 1931, came into effect on 1 March 1932..$^{91}$ In brief, they applied to all factories and workshops in which asbestos was processed or otherwise manipulated. While they did not apply to all areas of the factory, they did cover the dustiest processes. Aside from the preamble and a section of definitions, there were seventeen regulations, many of which contained clauses and sub-clauses. Of these regulations, twelve imposed obligations on employers and five on workers. In essence they sought to prevent the creation of dust and, where it was created, to prevent, either by the installation of exhaust ventilation or through the provision of breathing apparatus, the workforce from being exposed to it.

\section{Conclusion}

A number of points may be made about the process leading to the establishment of the Asbestos Industry Regulations, 1931. First, there are no convincing grounds for the argument that the regulations were established tardily, that is, long after the dangers of asbestos had been appreciated. Once the Factory Inspectorate became aware of the existence of a significant problem, following the work of Cooke and others in the mid to late 1920s, it moved speedily to investigate and tackle it. All accusations of delay derive from late-twentieth-century observers; none were made by interested parties at the time. Indeed, Legge congratulated the Factory Department for the speed of its response. Second, if the regulators were not dilatory, were they one-sided in their approach, showing more concern for the needs of manufacturers than those of workers? This question has been answered in the positive, at least by implication, by several late-twentieth-century observers, notably Greenberg and Wikeley. But, again, there is little evidence to support such an interpretation. Certainly, it is clear that the Factory Inspectorate consulted manufacturers before they consulted organized labour and also that the consultation process between regulators and employers was lengthier than that which took place between regulators and workers' representatives. To some extent this imbalance can be explained, as Wikeley acknowledges, in terms of "uncertainty within the Factory Department as to whether there were any specific trade unions operating in the asbestos trade." 92 Another explanation was put forward by Merewether. This was that "[p]roblems of ventilating engineering of the utmost difficulty had to be faced, particularly on the textile side of the industry", appreciation of which prompted "immediate steps" to confer with asbestos textile manufacturers. ${ }^{93}$ If dissatisfaction with the consultative process were likely to have been felt anywhere, it would have been among trade unionists. However, union leaders, while recognizing that the 1931 regulations did not give them everything they wanted, were satisfied with the fullness and fairness of the consultations which took place and were willing to accept the rules as a satisfactory outcome of negotiations. They may have been successful in amending the draft regulations only at the margins, but the

90 WMRC, op. cit., note 33 above, Sherwood to Smyth, 16 Sept. 1931; Smyth to Malcolm Delevingne, 23 Nov. 1931; extract from workmen's compensation and factories committee minutes, 23 Nov. 1931; G R Buckland (Home Office clerk) to Smyth, 8 Jan. 1932.

\footnotetext{
91 Statutory instruments, 1931, no. 1140. Some sections were deferred either for six or twelve months.

92 Wikeley, 'Asbestos Regulations', op. cit., note 1 above, p. 369.

93 Merewether, op. cit., note 17 above, p. 153.
} 


\section{Peter Bartrip}

manufacturers fared no better in this respect. Even if the unions and the TUC were less fully consulted than the employers in the making of the regulations, there is no doubt that organized labour played a large part in the process. ${ }^{94}$ As a result, it is legitimate to regard it as having been a major partner in the establishment of what were, in the end and with one minor exception, agreed rules. As Wikeley maintains: "The final version of the regulations was the result of a series of negotiations between the Home Office and the manufacturers, and subsequently between the Home Office and the TUC". 95

Third, if the regulations were, almost entirely, agreed by the three parties to the negotiations, was it perhaps the case that the manufacturers had to be dragged "kicking and screaming" to the conference table? Did their participation in negotiations reflect a recognition that it was in their interests to co-operate in producing minimal controls rather than to end up having really tough measures imposed upon them? Late-twentieth-century observers have stated, or at least implied, that self-interest characterized the employers' attitudes, but did organized labour and the Factory Department feel this at the time? The answer to this question must be in the negative, for neither of these bodies was critical of the approach of the employers. On the contrary, they applauded the asbestos manufacturers' responsible behaviour, both in running their works and in participating in the regulatory process. It was, Merewether pointed out in 1934:

. . . the evident desire of the leading manufacturers, as shown by the remarkable progress in dust suppression made in the past two years and their courage in dealing with the practical difficulties, which relieves the apprehension inevitably associated with a serious occupational disease, and cheers with the conviction of success. ${ }^{96}$

His point is endorsed by the verdict of two other medical authorities in respect of the conduct of Turner Brothers Asbestos before and during the negotiations leading to the 1931 regulations. Both call into question David Jeremy's assertion that TBA's response to the emergence of the asbestos hazard was one of "denial". ${ }^{97}$ First, Ian Grieve in his 1927 MD thesis, which was mainly based on studies undertaken at TBA's Leeds sister company, J W Roberts, noted: "If I have been afforded some opportunity of observing the conditions under which my patients are employed, it has been entirely due to the courtesy and enthusiasm of the management at Leeds". ${ }^{98}$ Second, Legge, in a letter to TBA in 1931, observed:

As Medical Inspector of Factories many years ago, I visited your factory near Rochdale and was even then impressed by what you were carrying out in locally applied exhaust ventilation. Now, after having read (and discussed at the Home Office) the Agreements as to Methods of Suppressing Dust in Asbestos Textile Factories, I realize how very much further you have applied exhaust ventilation. ${ }^{99}$

From a medical authority of Legge's credentials who was, moreover, in the employ of the TUC, this was a ringing endorsement of the high standards achieved by Turner Brothers.

\footnotetext{
94 See e.g., WMRC, op. cit., note 33 above, Legge's note, 25 Jan. 1932.

95 Wikeley, 'Asbestos Regulations', op. cit., note 1 above, p. 368; see Report of the sixty-fourth annual TUC congress, Newcastle-upon-Tyne, 1932, London, Co-operative Printing Society, 1932, p. 142.
}

96 Merewether, op. cit., note 17 above, p. 159.

97 Jeremy, op. cit., note 1 above, p. 258.

98 Grieve, op. cit., note 27 above, pp. 1-2.

99 WMRC, op. cit., note 33 above, Legge to Turner Brothers Asbestos Co., 1 Sept. 1931. 


\section{The Home Office and the Asbestos Industry Regulations, 1931}

It supported the opinion of Joseph Nuttall, secretary of the Rochdale Weavers' Association, who was "satisfied that the system in operation at Messrs Turner Bros, Rochdale is adequate for the purpose". ${ }^{100}$ Hence, at least as far as TBA is concerned, the charge that asbestos employers showed "a reluctance . . . to accept safety standards beyond the bare minimum to meet the risks", would seem to be unsustainable. ${ }^{101}$ In any case, in assessing such a charge it is important to ask which of the phrases in this extract, "bare minimum" or "meet the risks", warrants greater emphasis. The thrust of the MerewetherPrice report and of all subsequent moves towards the establishment of the 1931 regulations was that one thing alone was necessary to solve the acknowledged problem of fibrosis among asbestos workers. This was the reduction of dust levels to below the "dust datum". ${ }^{102}$ Although this expectation eventually proved to be ill founded, there are no grounds to suppose that it was not sincerely held in the late 1920s, throughout the 1930s, and indeed long after. Once this point is accepted it is easy to see why the manufacturers, in particular (though they were supported by Bridge), baulked at what they perceived to be, in the circumstances, unnecessary additional regulations which might undermine their competitiveness.

Of course, the true value of the 1931 regulations can be assessed only by evaluating their effectiveness once they were in operation. Did manufacturers comply with them and did the regulations produce the anticipated improvement in occupational health? Although a full investigation of such questions lies beyond the scope of this article, it is worth noting that there is clear statistical evidence that the asbestosis mortality rate declined in the years following implementation of the regulations. In 1957 the number of asbestos fatalities recorded by the Factory Inspectorate (18) was 100 per cent higher than the figure for 1931 . On the other hand the tonnage of raw and fibre asbestos imported and retained in the UK in 1957 was more than 600 per cent greater than in $1931 .{ }^{103}$ Comparisons for different years will yield different results, but one thing is certain: in relation to the size of the asbestos industry, the number of deaths from occupational asbestosis declined from the early 1930s. Richard Doll, who in the 1950s studied the relationship between asbestos and lung cancer, certainly concluded that the 1931 regulations had made the industry safer: "It is clear ... that the incidences both of asbestosis and of lung cancer associated with asbestosis have become progressively less as the number of years during which men were exposed to the pre-1933 conditions has decreased". ${ }^{104}$ Georgiana Bonser et al. were still more explicit:

... it must be emphasised that since the introduction of regulations for the control of asbestos dust in 1931, the amount of exposure of the workers to dust has been enormously reduced and we shall therefore expect to see a disappearance of those severe degrees of pulmonary fibrosis that have been described heretofore and possibly a disappearance of associated cancer. ${ }^{105}$

100 Ibid., Joseph Nuttall to TUC social insurance department, 22 July 1931.

101 Wikeley, 'Asbestos Regulations', op. cit., note 1 above, p. 369.

102 Wikeley, Compensation, op. cit., note 1 above, p. 110 .

103 Fatality figures are derived from the annual reports of HM Chief Inspector of Factories. Import data are taken from the Annual statement of the trade of the United Kingdom with foreign countries and
British possessions.

104 Richard Doll, 'Mortality from lung cancer in asbestos workers', Brit. J. ind. Med., 1955, 12: 81-6, p. 86.

105 Georgiana M Bonser, J S Faulds and M J Stewart, 'Occupational cancer of the urinary bladder in dyestuffs operatives and of the lung in asbestos textile workers and iron-ore miners', Am. J. clin. Path., 1955, 25: 126-34, p. 132. 


\section{Peter Bartrip}

There is also much evidence that the Factory Inspectorate was satisfied with the performance of the asbestos industry in complying with the 1931 regulations. Again, this is not the place fully to explore the point, but it is instructive to record Merewether's opinion, which he expressed in a letter to the chairman of Turner \& Newall:

Looking back over the years since 1928 when I first came in contact with your Organisation, I feel we have progressed in the great task of preventing asbestosis quicker than anyone would have expected. This has been very much due to the remarkable way in which the whole Industry, led by yourself, has thrown itself wholeheartedly into the solution of the very complex problems involved.

While we have, as you will agree, a long way to go yet, deaths, the result of very short exposure, do not occur nowadays. I think it unlikely that any other country in the world can say the same. Perhaps we may be able to tell the Americans something, in this connection at any rate. ${ }^{106}$

Finally, it is important to place the making of the Asbestos Industry Regulations within their proper context. This article has criticized some scholars for exaggerating, either explicitly or implicitly, certain aspects of the history of the asbestos question. These include the extent of medical and official knowledge of the dangers and the degree to which asbestos was identified as a particularly acute health hazard, the threat from which far outweighed that which was posed by any other occupational disease. It seems likely that such exaggeration owes much to the use of hindsight. In some cases the result has been what might be termed "presentist" history, that is the construction of historical accounts in which current knowledge, concerns, and perspectives dictate the depiction and interpretation of the past. The fact is that in the interwar period Factory Inspectors and others became aware of a number of more or less serious health hazards in the industrial workplace. These included byssinosis, dermatitis, silicosis, and ulcerations brought about by contact with various substances (especially mineral oil and chrome). On the basis of known fatalities, some industrial materials and by-products appeared at the time to be significantly more hazardous than asbestos. Accordingly, Factory Inspectors often devoted more attention to them than to asbestosis. In several instances a regulatory response involving investigations, reports, legislation, conferences with employers and organized labour, and the issue of rules took place. ${ }^{107}$ In other words, in the period under review asbestos was not seen to be uniquely dangerous, but merely one hazard which could be brought under control, through the sensible application of appropriate measures.

$106 \mathrm{~T} \& \mathrm{~N}$ Archive, op. cit., note 25 above, drawer 63, Merewether to Sir Samuel Turner, 22 Sept. 1942.

107 See, e.g., Alan Fowler and T J Wyke (eds),

The barefoot aristocrats: $a$ history of the Amalgamated Association of Operative Cotton
Spinners, Littleborough, George Kelsall, 1987, ch. 10; A J McIvor, 'Manual work, technology, and industrial health, 1918-39', Med. Hist., 1987, 31 : $160-89$. 